\title{
DWANGSTOORNISSEN IN DE PRAKTIJK
}

Menno Oosterhoff. Vals Alarm. Hilversum: uitgeverij Lucht BV, 2017. 367 pagina's. ISBN 978-94-9172-968-3. Prijs paperback € 22,50 of ebook $€ 9,99$

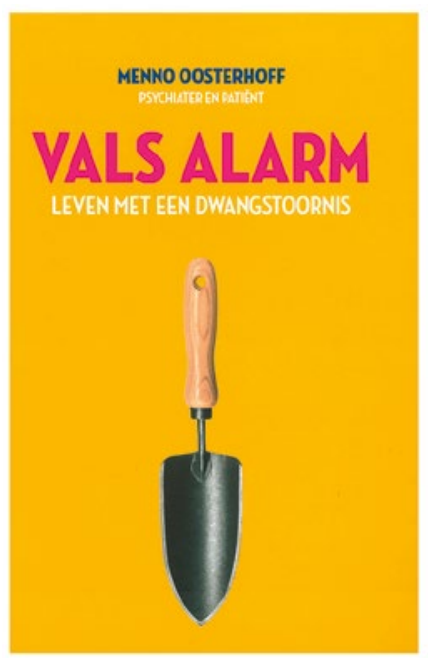

Psychiater Menno Oosterhoff is gespecialiseerd in dwangstoornissen. Hij is ook ervaringsdeskundige. In dit boek beschrijft hij op creatieve wijze de impact van dwangstoornissen op het persoonlijke, sociale en maatschappelijke leven en maakt zijn unieke kennis voor iedereen toegankelijk. Oosterhoff maakt het graduele disfunctioneren zichtbaar aan de hand van alledaagse, voor iedereen herkenbare voorbeelden tot en met extreme obsessies en compulsies.

Een dwangstoornis is voor de patiënt een plaag en doet zich voor in een geleidelijke schaal van lichte controledwang tot hardnekkige dwanggedachten (obsessies) en dwanghandelingen (compulsies). Zo'n 1 tot $2 \%$ van de bevolking lijdt eraan. Nog niet zo lang geleden dachten artsen dat dwang voortkwam uit angst, maar zij hebben dit idee losgelaten. Patiënten ervaren een obsessieve onrust als iets 'niet helemaal goed voelt' (just-not-right-feeling) of als iets onvolledig of onaf is (feeling of incompleteness). Deze onrust leidt tot het uitvoeren van dwanghandelingen, maar hierdoor nemen de problemen juist toe. In de behandeling gaat het erom de onrust te leren verdragen. Onvolkomenheden horen nu eenmaal bij het leven. Mensen met dwang zijn gewend rekening te houden met het ergste en zoeken absolute zekerheden. Maar hoe zeker is zeker? Via algemene wijsheden oftewel 'dooddoeners' corrigeert Oosterhoff zijn patiënten en leert hen dat 'goed genoeg' effectiever is dan nastreven van perfectie. Hij is een meester in het eenvoudig uitleggen van de werkingsmechanismen bij dwang. Dat doet hij met metaforen en leuke anekdotes. Huisartsen kunnen hiervan leren. Drukke huisartsen raad ik aan om de hoofdstukken 1, 2, 7 en 8 te lezen. Mooi is ook hoofdstuk 13, waarin Menno's vrouw vertelt over de betekenis van een dwangstoornis voor de gezinsleden.

Marian Oud

WAARDERING: 